\title{
Penerapan teknik pembenihan dan budidaya ikan baung di Desa Batu Belah, Kecamatan Kampar, Riau
}

\author{
Sukendi*, Thamrin, Ridwan Manda Putra \\ Fakultas Perikanan dan Kelautan, Universitas Riau \\ *p.sukendims@yahoo.com
}

\begin{abstract}
The purpose of this community service program (PKM) is to provide knowledge and technology on the techniques of hatchery and fish cultivation in Batu Belah Village, Kampar District especially in the Lele Sejahtera Hatchery Group and Mina Karya Fish Farming Group (Pokdakan). The method used in this PKM activity is the method of lectures, discussions and direct demonstrations in the field. The results of the evaluation show that there were changes in knowledge from 10 participants, members of the Prosperous People's Hatchery Group (KPR) known as seven people $(70.00 \%)$ had been able to absorb the material given with a very good predicate, the other participants were in good and sufficient categories. Furthermore, of the 11 participants in the Mina Karya Fish Cultivation Group (Pokdakan) it was found that eight people (72.23\%) had been able to absorb the material given in very good categories, the other participants were in the right and sufficient categories. The results of the evaluation of this skill show that the participants of the activity have been able to practice the material on hatchery through artificial spawning and Baung fish cultivation technology. Furthermore, the results of the impact evaluation are known to show that the impact of this PKM activity has been felt by the members of the two existing farming groups so that it can increase the income of the members of the two farmer groups, and at the same time improve their welfare.
\end{abstract}

\begin{abstract}
Absrak Tujuan dari kegiatan program ini adalah untuk memberikan ilmu dan teknologi tentang teknik pembenihan dan budidaya ikan baung di Desa Batu Belah, Kecamatan Kampar khususnya pada Kelompok Pembenihan Rakyat (KPR) Lele Sejahtera dan Kelompok Budidaya Ikan (Pokdakan) Mina Karya. Metode yang digunakan dalam kegiatan PKM ini adalah metode ceramah, diskusi dan demonstrasi langsung ke lapangan. Hasil evaluasi perubahan pengetahuan dari 10 orang peserta anggota Kelompok Pembenihan Rakyat (KPR) Lele Sejahtera diperoleh 7 orang $(70,00 \%)$ telah dapat menyerap materi yang diberikan dengan predikat sangat baik selebihnya predikat baik dan cukup. Selanjutnya dari 11 orang peserta anggota Kelompok Budidaya Ikan (Pokdakan) Mina Karya diperoleh 8 orang $(72,23 \%)$ telah dapat menyerap materi yang diberikan dengan predikat sangat baik, selebihnya predikat baik dan cukup. Hasil evaluasi keterampilan menunjukkan bahwa peserta kegiatan telah dapat mempraktekkan materi tentang pembenihan ikan baung melalui pemijahan buatan dan teknologi budidaya budidaya ikan baung. Selanjutnya dari hasil evaluasi dampak menunjukkan dampak kegiatan ini telah dirasakan menfaatnya oleh anggota kedua kelompok tani yang ada, sehingga akan dapat meningkatkan pendapatan anggota kedua kelompok tani tersebut, sekaligus dapat meningkatkan kesejahteraannya.
\end{abstract}

Keywords: hatchery; cultivation; fish; baung; evaluation; category

\section{¿ OPEN ACCESS}

Citation: Sukendi, Thamrin, dan R.M. Putra 2018. Penerapan teknik pembenihan dan budidaya ikan baung di Desa Batu Belah, Kecamatan Kampar, Riau. Riau Journal of Empowerment 1(2): 51-60 https://doi.org/10.31258/raje.1.2.7

Received: 2018-09-20, Revised: 2018-10-20, Accepted: 2018-11-07

Language: Bahasa Indonesia (id)

C 2018 Sukendi et al. The article by Author(s) is licensed under a Creative Commons Attribution 4.0 International License. This license permits unrestricted use, distribution, and reproduction in any medium, provided the original author and source are credited. 


\section{PENDAHULUAN}

Desa Batu Belah merupakan salah satu desa yang terletak di Kecamatan Kampar, Kabupaten Kampar Provinsi Riau yang memiliki prospek pengembangan perikanan air tawar, baik pengembangan bidang pembenihan untuk menghasilkan benih maupun pengembangan bidang pembesaran untuk menghasilkan ikan ukuran konsumsi. Di Desa Batu Belah Kecamatan Kampar, Kabupaten Kampar ini terdapat dua kelompok tani yang bergerak dalam bidang perikanan. Kelompok tani tersebut adalah "Kelompok Pembenihan Rakyat (KPR) Lele Sejahtera" yang bergerak dalam bidang pembenihan ikan lele dumbo (Clarias gariepinus Burchell) untuk menghasilkan benih dan "Kelompok Budidaya Ikan (Pokdakan) Mina Karya" yang bergerak dalam bidang budidaya ikan lele dumbo di kolam untuk menghasilkan ikan konsumsi. Permasalahan yang ditemukan pada kedua kelompok tani ini adalah jenis ikan yang dikembangkan hanya satu jenis ikan lele dumbo, selain itu juga manajemen yang dilakukan masih bersifat tradisional, dimana untuk produksi benih oleh kelompok Pembenihan Rakyat (KPR) Lele Sejahtera masih dilakukan melalui metode pemijahan semi alami, begitu juga untuk produksi ikan konsumsi oleh Kelompok Budidaya Ikan (Pokdakan) Mina Karya dilakukan melalui metode budidaya semi intensif, dimana pakan yang diberikan sebagian masih tergantung dari alam, sehingga produksi benih maupun ikan ukuran konsumsi yang diperoleh kedua kelompok tani tersebut masih sangat terbatas.

Untuk menyelesaikan permasalahan tersebut maka perlu diberikan ilmu dan teknologi tentang teknologi pembenihan ikan baung melalui pemijahan buatan pada Kelompok Pembenihan Rakyat (KPR) Lele Sejahtera dan teknologi budidaya ikan baung secara intensif pada Kelompok Budidaya Ikan (Pokdakan) Mina Karya. Hal ini karena ikan baung jauh lebih ekonomis dibandingkan dengan ikan lele dumbo yang dikembangkan oleh kedua kelaompok tani tersebut selama ini, dimana harga dalam bentuk segar mencapai 50 ribu rupiah sampai 75 ribu rupiah perkilogram sedangkan bila dalam bentuk ikan asap atau yang dikenal dengan ikan salai dapat mencapai 150 ribu sampai 200 ribu perkilogram (Sukendi, 2012).

Saanin (1984) dan Kottelat et al. (1993) menyatakan bahwa ikan baung dapat diklassifikasikan ke dalam filum Chordata, kelas Pisces, sub kelas Teleostei, ordo Siluriformes, sub-ordo Siluridae, familia Bagridae genus Mystus dan spesies Mystus nemuru $C V$. Penelitian tentang pengamatan reproduksi di alam hingga teknologi pembenihannya di alam terkontrol telah berhasil dilakukan (Sukendi, 2001). Dikatakan juga keadaan kualitas air tempat hidup ikan ini adalah suhu antara 24-29 0C, derajat keasaman $(\mathrm{pH})$ antara 6,5-8, kandungan oksigen menimal 4 ppm dan air yang tidak terlalu keruh (Sukendi, 2001). Kebiasaan makan ikan baung tergolong kedalam ikan pemakan segala (omnivora), dengan makanan terdiri dari anak ikan, udang remis, insekta, moluska dan rumput (Djajadiredja et al., 1977; Samuel dan Adjie, 1994), dan mengarah ke pemakan daging (karnivora) (Alawi et al., 1992). Alawi et al. (1992) menyatakan bahwa jenis ikan yang menjadi makanan ikan baung adalah dari famili Cyprinidae, yaitu ikan motan (Thynnichthys sp), kapiek (Puntius $s p$ ) dan selais (Siluroides $s p$ ), selain itu jenis udang yang dimakan ikan ini adalah dari spesies Macrobrachium $s p$, sedangkan jenis detritus yang dimakan terdiri dari potongan dedaunan, akar kayu dan hancuran ikan dan kumbang yang tidak bisa diidentifikasi.

Hormon yang umum digunakan untuk pemijahan ikan baung adalah ovaprim dengan dosis $0,9 \mathrm{ml} / \mathrm{kg}$ bobot induk untuk ikan betina dan $0,5 \mathrm{ml} / \mathrm{kg}$ bobot induk untuk ikan jantan (Sukendi, 2007). Menurut Nandeesha et al. (1990) dan Harker (1992) ovaprim merupakan kombinasi dari analog salmon gonadotropin Releasing Hormon (sGnRH-a) ((D-Arg ${ }^{6}, \mathrm{Trp}^{7}, \mathrm{Leu}^{8}, \mathrm{Pro}^{9}-$ NET) - LHRH dan $10 \mathrm{mg}$ anti dopamin yang berperan untuk pematangan sel telur dalam ovarium.

Salah satu kriteria persyaratan kolam untuk pemeliharaan ikan baung adalah memiliki kadar oksigen terlarut yang tinggi, hal ini dapat diperoleh dengan membuat kolam yang sumber airnya mengalir. Kriteria ini tidak harus dimiliki oleh jenis ikan catfish lainnya seperti ikan lele dumbo (Clarias gariepinus Burchell) dan ikan patin (Pangasius sutchi) (Sukendi, 2007). Penelitian tentang keberhasilan budidaya ikan baung di kolam telah dilakukan sebelumnya (Badan Penelitian dan Pengembangan daerah Kabupaten Kampar kerjasama dengan Fakultas Perikanan dan Ilmu Kelautan Universitas Riau dalam Sukendi, 2007). Hasil 
penelitian menunjukkan bahwa ikan baung yang dipelihara selama 3 bulan dalam kolam ukuran 8 x 14 m dengan padat tebar 1000 ekor dan selama pemeliharaan diberi pakan pellet produksi CHAROEN POKPHAN dengan kandungan protein $28 \%$, pada dosis $5 \% / \mathrm{kg}$ bobot tubuh dengan pemberian 3 kali sehari menghasilkan pertumbuhan bobot mutlak antara 57,872-60,120 gram, laju pertumbuhan bobot harian berkisar antara 8,05-8,09\% dan pertumbuhan panjang mutlak antara $14,135-14,335 \mathrm{~cm}$

Menurut Sukendi (2007) ada beberapa hal yang harus dilakukan terhadap kolam sebelum ikan baung di tebar, yaitu 1) pengeringan dasar kolam, 2) pengangkutan lumpur di kolam, 3) perbaikan pematang dan pintu air, 4) pengapuran, 5) pemupukan, 60 pengisian air, 7) pemberatasan hama dan penyakit dan 8) pengisian air lanjutan.

\section{METODE PELAKSANAAN}

Metode yang digunakan untuk menyelesaikan persoalan pada Kelompok Pembenihan Rakyat (KPR) Lele Sejahtera yang merupakan mitra pertama dalam kegiatan Program Kemitraan Masyarakat (PKM) ini adalah dengan melakukan pembenihan ikan baung melalui pemijahan buatan. Pada pemijahan buatan akan dilakukan dengan menggunakan hormon ovaprim. Hal ini karena ovaprim merupakan kombinasi dari analog salmon gonadotropin Releasing Hormon

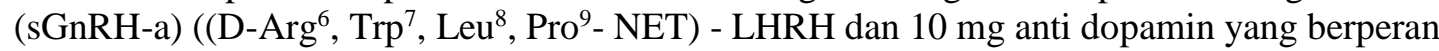
untuk pematangan sel telur dalam ovarium (Nandeesha et al., 1990; Harker, 1992). Beberapa hasil penelitian tentang penggunaan dosis ovaprim untuk meningkatkan daya rangsang ovulasi dan kualitas telur serta volume semen dan kualitas spermatozoa ikan baung serta beberapa jenis ikan air tawar dalam teknologi pembenihan melalui pemijahan bauatan dapat dilihat pada Tabel 1.

Tabel 1. Penggunaan dosis penyuntikan ovaprim yang terbaik untuk meningkatkan daya rangsang ovulasi dan kualitas telur serta volume semen dan kualitas spermatozoa beberapa jenis ikan air tawar

\begin{tabular}{|c|c|c|c|c|}
\hline No & Jenis Ikan & $\begin{array}{c}\text { Dosis Ovaprim yang } \\
\text { terbaik }\end{array}$ & $\begin{array}{l}\text { Respon yang } \\
\text { diukur }\end{array}$ & Sumber \\
\hline 1 & Lele betina & $0,50 \mathrm{ml} / \mathrm{kg}$ bobot tubuh & $a$ dan $b$ & Sukendi dkk, 1996 \\
\hline 2 & Lele jantan & $0,40 \mathrm{ml} / \mathrm{kg}$ bobot tubuh & d dan e & Nurman, 1995 \\
\hline 3 & Lele betina & $0,50 \mathrm{ml} / \mathrm{kg}$ bobot tubuh & $\mathrm{c}$ & Sukendi, 1995 \\
\hline 4 & Betutu betina & $0,90 \mathrm{ml} / \mathrm{kg}$ bobot tubuh & $a$ dan $b$ & Sukendi, 1996 \\
\hline 5 & Ikan sumatera betina & $1,00 \mathrm{ml} / \mathrm{kg}$ bobot tubuh & $\mathrm{b}$ & Sukendi, 1996 \\
\hline 6 & Klemak jantan & $0,50 \mathrm{ml} / \mathrm{kg}$ bobot tubuh & d dan e & $\begin{array}{l}\text { Putra dan Sukendi, } \\
1998\end{array}$ \\
\hline 7 & Betutu jantan & $0,60 \mathrm{ml} / \mathrm{kg}$ bobot tubuh & $\mathrm{d}$ dan e & $\begin{array}{l}\text { Putra dan Sukendi, } \\
2000\end{array}$ \\
\hline 8 & Baung betina & $0,90 \mathrm{ml} / \mathrm{kg}$ bobot tubuh & $\mathrm{a}, \mathrm{b}$ dan $\mathrm{f}$ & $\begin{array}{l}\text { Putra dkk, 2000; } \\
\text { Sukendi, } 2001\end{array}$ \\
\hline 9 & Baung jantan & $0,50 \mathrm{ml} / \mathrm{kg}$ bobot tubuh & $\mathrm{d}$, e dan $\mathrm{f}$ & Sukendi, 2001 \\
\hline 10 & Kapiek betina & $0,60 \mathrm{ml} / \mathrm{kg}$ bobot tubuh & $a$ dan $b$ & Sukendi dkk, 2006 \\
\hline 11 & Kapiek jantan & $0,50 \mathrm{ml} / \mathrm{kg}$ bobot tubuh & $\mathrm{d}$, e dan $\mathrm{f}$ & Sukendi dkk, 2006 \\
\hline 12 & Motan betina & $0,70 \mathrm{ml} / \mathrm{kg}$ bobot tubuh & $a$ dan $b$ & $\begin{array}{l}\text { Sukendi dkk (2010a; } \\
\text { 2010b) }\end{array}$ \\
\hline 13 & Selais jantan & $0,90 \mathrm{ml} / \mathrm{kg}$ bobot tubuh & d dan e & Putra dkk, 2011 \\
\hline 14 & Motan jantan & $0,70 \mathrm{ml} / \mathrm{kg}$ bobot tubuh & $\mathrm{d}$, e dan $\mathrm{f}$ & Sukendi, 2012 \\
\hline 15 & Senggaringan betina & $0,70 \mathrm{ml} / \mathrm{kg}$ bobot tubuh & $a$ dan $b$ & Sukendi dkk, 2014 \\
\hline 16 & Senggaringan jantan & $0,40 \mathrm{ml} / \mathrm{kg}$ bobot tubuh & $\mathrm{d}$ & Sukendi dkk, 2014 \\
\hline
\end{tabular}




\begin{tabular}{ccccc}
\hline No & Jenis Ikan & $\begin{array}{c}\text { Dosis Ovaprim yang } \\
\text { terbaik }\end{array}$ & $\begin{array}{c}\text { Respon yang } \\
\text { diukur }\end{array}$ & Sumber \\
\hline 17 & Pawas betita & $0,60 \mathrm{ml} / \mathrm{kg}$ bobot tubuh & a dan $\mathrm{b}$ & Sukendi dkk, 2015 \\
18 & Pawas jantan & $0,50 \mathrm{ml} / \mathrm{kg}$ bobot tubuh & $\mathrm{d}$ dan $\mathrm{e}$ & Sukendi dkk, 2015 \\
\hline Keterangan: & $a$ & $=$ & Daya rangsang ovulasi (waktu laten) & \\
& $b$ & $=$ Kualitas telur (diameter, kematangan, fertilitas dan daya tetas telur) \\
$c$ & $=$ Kematangan gonad secara histology & \\
$d$ & $=$ Volume semen & \\
$e$ & $=$ Kualitas spermatozoa (konsentrasi, motilitas, viabilitas, fertilitas dan daya tetas) \\
$f$ & $=$ Kelangsunghidupan larva, pertumbuhan panjang dan bobot larva
\end{tabular}

Selanjutnya metode yang digunakan untuk menyelesaikan persoalan pada Kelompok Budidaya Ikan (Pokdakan) Mina Karya yang merupakan mitra kedua dalam kegiatan Program Kemitraan Masyarakat (PKM) ini adalah dengan melakukan budidaya melalui teknik budidaya intensif. Metoda yang digunakan dalam kegiatan pembenihan melalui pemijahan buatan pada Kelompok Pembenihan Rakyat (KPR) Lele Sejahtera dan kegiatan budidaya intensif pada Kelompok Budidaya Ikan (Pokdakan) Mina Karya Desa Batu Belah, Kecamatan Kampar, Kabupaten Kampar, Riau ini adalah dengan metode ceramah, diskusi dan demonstrasi langsung ke lapangan. Evaluasi untuk melihat keberhasilan dari kegiatan yang dilakukan dibedakan menjadi: 1) Evaluasi perubahan pengetahuan dilakukan dengan pre test dan post test. Selisih antara post test dan pretest dinyatakan dalam persen (\%). 2) Evaluasi keterampilan dilakukan dengan cara menghitung beberapa keberhasilan teknologi pembenihan ikan baung melalui pemijahan buatan yang dilakukan oleh Kelompok Pembenihan Rakyat (KPR) Lele Sejahtera dan teknologi budidaya intensif ikan baung yang dilakukan oleh Kelompok Budidaya Ikan (Pokdakan) Mina Karya. 3) Evaluasi dampak dilakukan dengan cara observasi langsung di lapangan dan melihat dampak kegiatan yang telah dilakukan terhadap perubahan yang terjadi.

\section{HASIL DAN KETERCAPAIAN SASARAN}

Kegiatan program kemitraan masyarakat (PKM) tentang teknologi pembenihan ikan baung melalui pemijahan buatan pada Kelompok Pembenihan Rakyat (KPR) Lele Sejahtera dan teknologi budidaya melalui teknologi budidaya intensif ikan baung pada Kelompok Budidaya Ikan (Pokdakan) Mina Karya Desa Batu Belah, Kecamatan Kampar, Kabupaten Kampar, Riau telah terlaksana dengan baik. Kegiatan ini diikuti oleh 10 orang anggota Kelompok Pembenihan Rakyat (KPR) Lele Sejahtera dan 11 orang anggota Kelompok Budidaya Ikan (Pokdakan) Mina Karya. Pada saat kegiatan ceramah dan diskusi yang diberikan oleh tim pelaksana terlihat semua anggota kelompok yang hadir memiliki antusias yang tinggi. Hal ini terlihat semua anggota yang hadir mengajukan pertanyaan-pertanyaan yang berhubungan dengan materi yang diberikan. Peserta rata-rata sebelumnya tidak memahami bahwa ternyata teknologi pembenihan ikan baung melalui pemijahan buatan yang dilakukan tidak jauh berbeda dengan teknologi pembenhan ikan lele dumbo melalui pemijahan buatan yang dilakukan selama ini. Sementara dihitung dari nilai ekonomisnya benih ikan baung yang diperoleh jauh lebih tinggi daripada benih ikan lele dumbo yang diperoduksi selama ini. Selanjutnya anggota Kelompok Budidaya Ikan (Pokdakan) Mina Karya juga sebelumnya tidak mengetahui cara melakukan budidaya ikan baung secara intensif, dimana cara budidaya ini tidak jauh berbeda dengan budidaya ikan lele dumbo yang dilakukan selama ini, sementara nilai ekonomis ikan baung ukuran konsumsi jauh lebih tinggi daripada ikan lele dumbo.

Materi yang sangat menarik bagi anggota Kelompok Pembenihan Rakyat (KPR) Lele Sejahtera adalah cara penentuan dosis ovaprim yang tepat, cara menentukan ciri induk ikan baung jantan dan betina matang gonad, cara penyuntikan, cara striping/pengurutan, penyuntikan dan cara menentukan keberhasilan fertilisasi. Kenyataan ini karena menurut anggota kelompok tani hal tersebut yang selalu menjadi kegagalan dalam melakukan pembenihan ikan lele dumbo melalui pemijahan buatan selama ini. Dokumentasi kegiatan 
pembenihan melalui pemijahan buatan anggota Kelompok Pembenihan Rakyat (KPR) Lele Sejahtera yang dilakukan dapat dilihat pada Gambar 1.
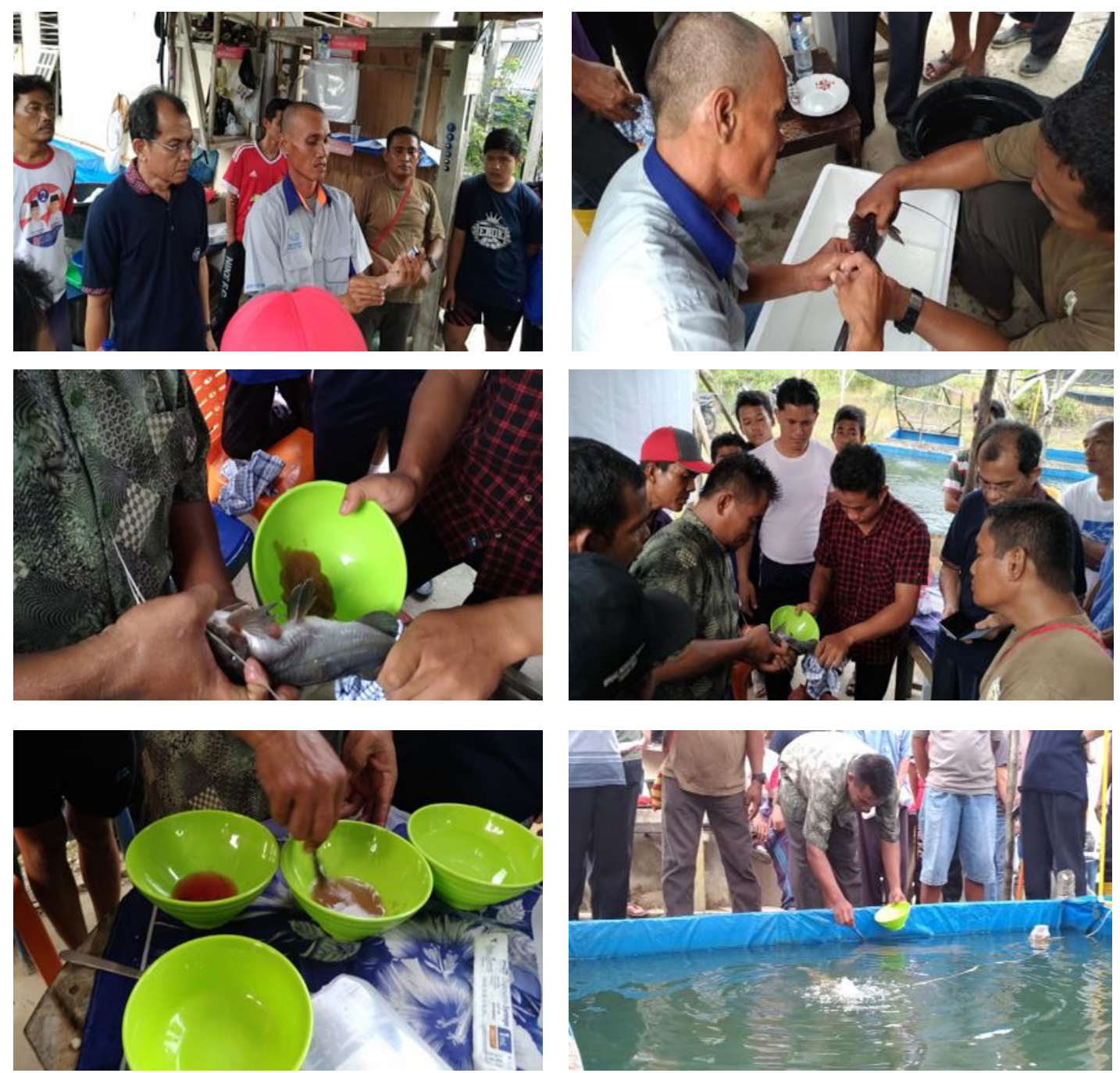

Gambar 1. Penentuan dosis ovaprim untuk penyuntikan, penyuntikan pada induk ikan baung, stripping pada induk ikan baung betina, stripping pada induk ikan baung jantan, percampuran telur dan semen serta penebaran telur ke bak penetasan

Selanjutnya materi tentang teknologi budidaya melalui teknologi budidaya intensif ikan baung yang diberikan, ternyata yang sangat menarik bagi anggota Kelompok Budidaya Ikan (Pokdakan) Mina Karya adalah cara menentukan padat tebar dan cara penebaran benih ikan baung pada awal pemeliharaan di kolam, cara menentukan bahan pembuatan pakan buatan (pellet) dan cara pembuatannya. Hal ini karena beberapa parameter tersebut di atas yang selalu menjadi kegagalan dalam melakukan budidaya ikan lele dumbo selama ini. Yang sangat bermanfaat bagi para anggota Kelompok Budidaya Ikan (Pokdakan) Mina Karya dari materi yang diberikan adalah cara menentukan bahan pembuatan pakan buatan (pellet) dan cara pembuatannya. Hal ini karena biaya penyediaan pakan untuk budidaya ikan lele dumbo yang dilakukan selama ini sangat besar. Dokumentasi kegiatan pembuatan pellet pada anggota Kelompok Budidaya Ikan (Pokdakan) Mina Karya dapat dilihat pada Gambar 2.

\section{Hasil Evaluasi Perubahan Pengetahuan}

Hasil evaluasi perubahan pengetahuan terhadap 10 orang anggota Kelompok Pembenihan Rakyat (KPR) Lele Sejahtera menunjukkan bahwa 7 orang $(70,00 \%)$ telah dapat menyerap materi yang diberikan dengan predikat sangat baik (nilai A), 2 orang $(20,00 \%)$ dapat menyerap materi yang diberikan dengan predikat baik (nilai B), 1 orang $(10,00 \%)$ dapat menyerap materi dengan predikat cukup (nilai C), sedangkan yang memperoleh predikat kurang (nilai D) dan 
kurang sekali (nilai E) tidak ditemukan (Gambar 3). Selanjutnya hasil evaluasi perubahan pengetahuan terhadap 11 orang anggota Kelompok Budidaya Ikan (Pokdakan) Mina Karya menunjukkan bahwa 8 orang $(72,23 \%)$ telah dapat menyerap materi yang diberikan dengan predikat sangat baik ( nilai A), 2 orang $(18,18 \%)$ dapat menyerap materi yang diberikan dengan predikat baik (nilai B), 1 orang $(9,09 \%)$ dapat menyerap materi dengan predikat cukup (nilai C), sedangkan yang memperoleh predikat kurang (nilai D) dan kurang sekali (nilai E) tidak ditemukan (Gambar 4).
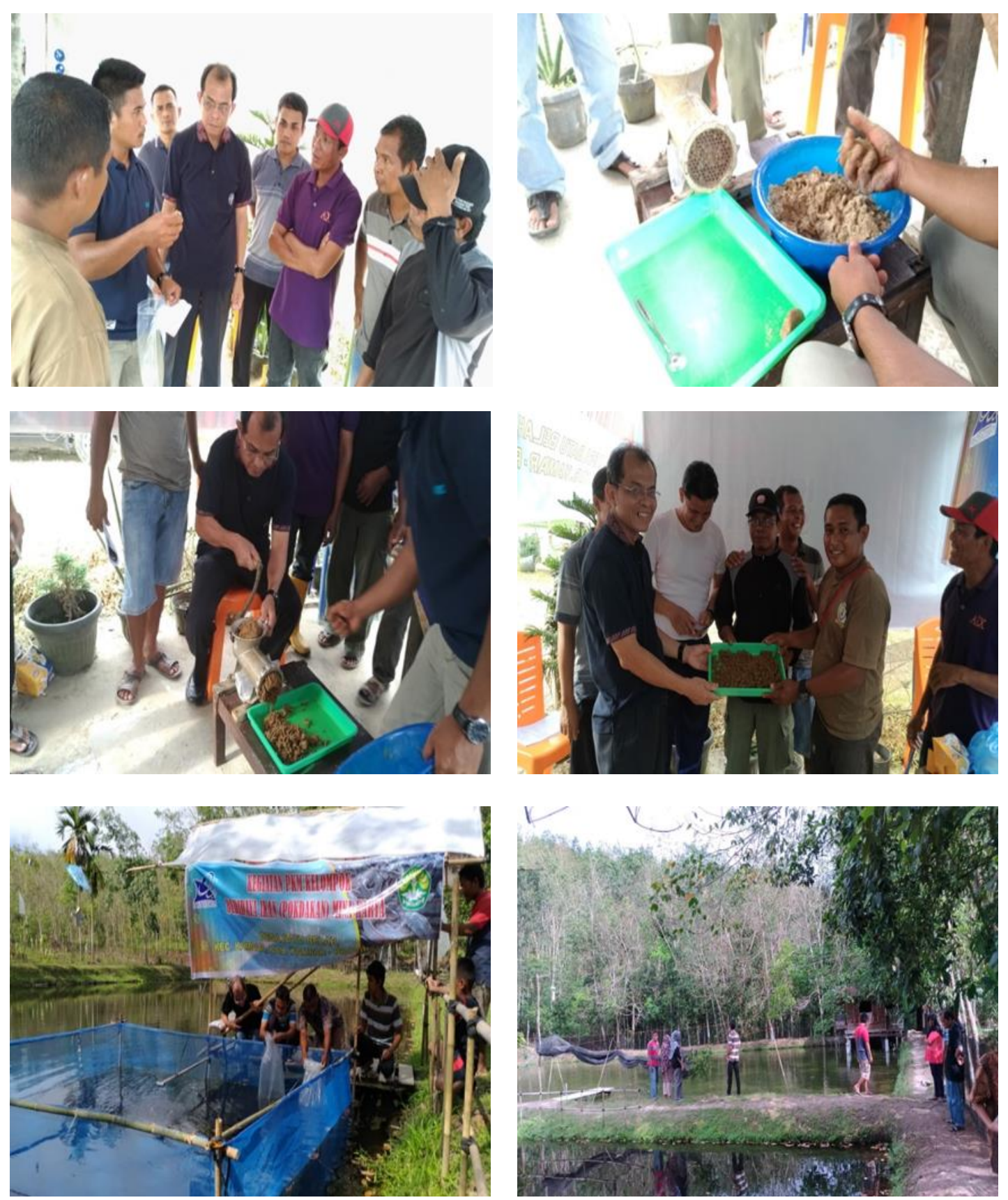

Gambar 2. Penentuan dosis bahan pembuat pellet, pengadukan bahan pembuat pellet, pencetakan pellet, pellet sudah jadi siap untuk dijemur, penebaran benih ikan baung dan kolam pembesaran ikan baung 


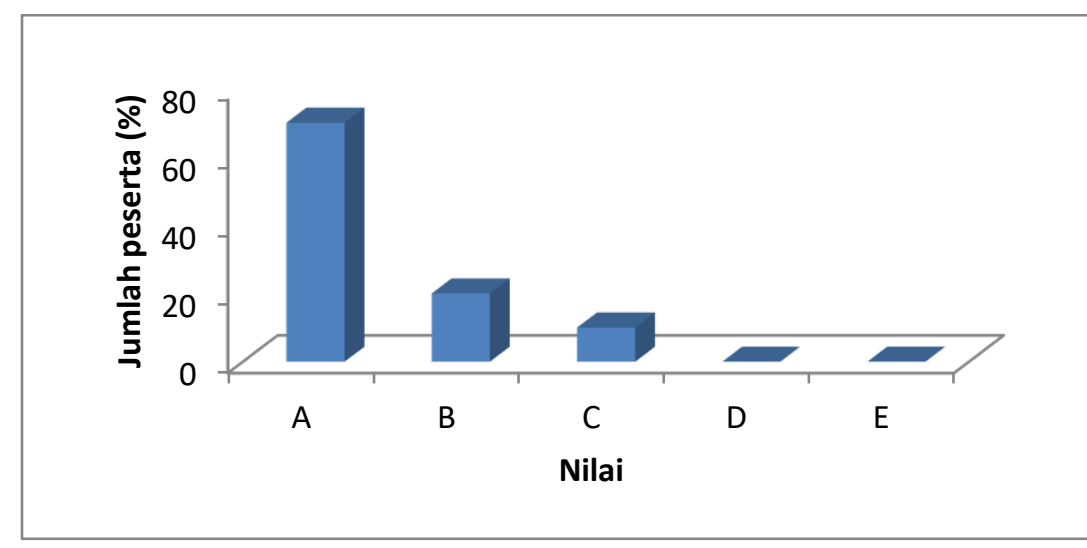

Sukendi dkk.

Gambar 3. Histogram hasil evaluasi perubahan pengetahuan kegiatan program kemitraan masyarakat (PKM) tentang teknologi pembenihan ikan baung melalui pemijahan buatan pada Kelompok Pembenihan Rakyat (KPR) Lele Sejahtera, Desa Batu Belah, Kecamatan Kampar, Kabupaten Kampar, Riau

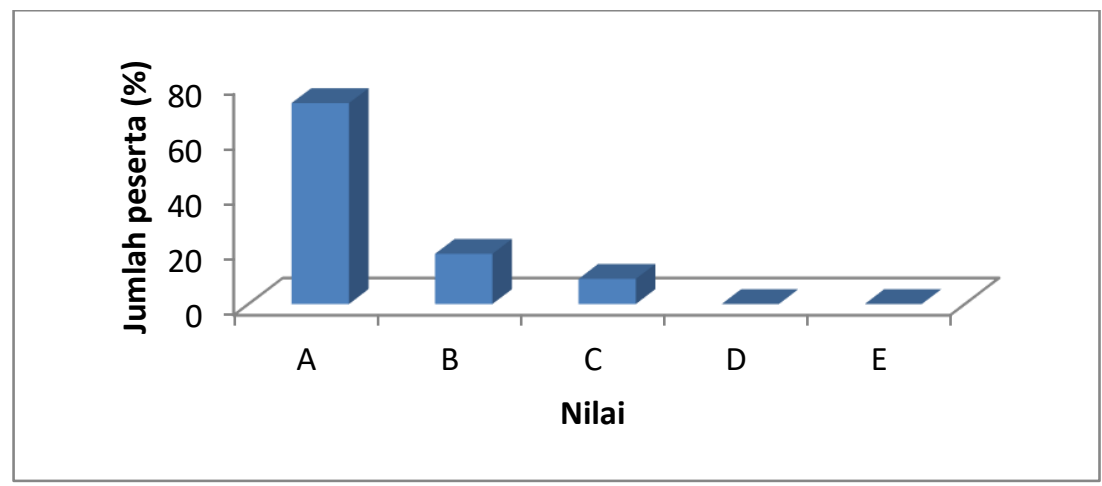

Gambar 4. Histogram hasil evaluasi perubahan pengetahuan kegiatan program kemitraan masyarakat (PKM) tentang teknologi budidaya melalui teknologi budidaya intensif ikan baung pada Kelompok Budidaya Ikan (Pokdakan) Mina Karya Desa Batu Belah, Kecamatan Kampar, Kabupaten Kampar, Riau

\section{Hasil Evaluasi Keterampilan}

Hasil evaluasi keterampilan menunjukkan bahwa anggota Kelompok Pembenihan Rakyat (KPR) Lele Sejahtera telah melakukan teknologi pembenihan ikan baung melalui pemijahan buatan pada Hachery mini yang dimiliki sesuai dengan teknologi yang diberikan pada kegiatan ceramah dan diskusi dilakukan sebelumnya. Selanjutnya hasil evaluasi keterampilan yang dilakukan pada anggota Kelompok Budidaya Ikan (Pokdakan) Mina Karya menunjukkan bahwa para anggota kelompok tani telah melakukan pula teknologi budidaya intensif ikan baung pada kolam yang dimiliki sesuai dengan teknologi yang diberikan pada kegiatan ceramah dan diskusi dilakukan sebelumnya. Para anggota kelompok tani selain membudidayakan ikan patin dan lele juga telah mencoba membudidayakan ikan baung. Kegiatan budidaya ikan baung yang dilakukan oleh kelopok tani memiliki prospek yang besar di masa mendatang, kaena sumber air kolam yang dimiliki bersal dari sumber air anak sungai yang terus mengalir, sehingga air kolam yang ada terus berganti.

\section{Hasil Evaluasi Dampak}

Hasil evaluasi dampak menunjukkan bahwa dampak kegiatan ini telah dirasakan oleh anggota Kelompok Pembenihan Rakyat (KPR) Lele Sejahtera dan anggota Kelompok Budidaya Ikan (Pokdakan) Mina Karya. Dengan dirasakannya dampak kegiatan yang telah diberikan akan dapat pula meningkatkan hasil produksi dan sekaligus meningkatkan kesejahteraan anggota dari kedua kelompok tani ikan tersebut. 


\section{KESIMPULAN DAN SARAN}

\section{Kesimpulan}

Dari hasil kegiatan program kemitraan masyarakat (PKM) yang telah dilakukan dapat disimpulkan sebagai berikut:

1. Anggota Kelompok Pembenihan Rakyat (KPR) Lele Sejahtera memiliki antusias yang tinggi terhadap teknologi pembenihan ikan baung melalui pemijahan buatan yang diberikan, begitu juga anggota Kelompok Budidaya Ikan (Pokdakan) Mina Karya terhadap teknologi budidaya melalui teknologi budidaya intensif ikan baung yang diberikan, hal ini terlihat dari hasil evaluasi perubahan pengetahuan dimana rata-rata peserta dapat meyerap materi yang diberikan dengan predikat terbanyak sangat baik (nilai A).

2. Hasil evaluasi keterampilan yang dilakukan terhadap Kelompok Pembenihan Rakyat (KPR) Lele Sejahtera tentang teknologi pembenihan ikan baung melalui pemijahan buatan maupun terhadap Kelompok Budidaya Ikan (Pokdakan) Mina Karya tentang teknologi budidaya melalui teknologi budidaya intensif ikan baung menunjukkan bahwa peserta kegiatan telah dapat mempraktekkan langsung kegiatan yang telah diberikan di lapangan sesuai dengan teknik yang telah diberikan sebelumnya pada kegiatan ceramah dan diskusi

3. Hasil evaluasi dampak yang dilakukan terhadap Kelompok Pembenihan Rakyat (KPR) Lele Sejahtera tentang teknologi pembenihan ikan baung melalui pemijahan buatan maupun terhadap Kelompok Budidaya Ikan (Pokdakan) Mina Karya tentang teknologi budidaya melalui teknologi budidaya intensif ikan baung menunjukkan bahwa kegiatan ini telah dirasakan menfaatnya oleh anggota kedua kelompok tani yang ada, sehingga akan dapat meningkatkan pendapatan anggota kedua kelompok tani tersebut dan sekaligus akan dapat meningkatkan kesejahteraannya.

4. Kendala yang ditemukan oleh Kelompok Pembenihan Rakyat (KPR) Lele Sejahtera dalam melakukan teknologi pembenihan ikan baung melalui pemijahan buatan adalah sulitnya mendapatkan induk ikan baung jantan dan betina matang gonad yang siap untuk dipijahkan, namun kendala ini dapat diatasi dengan cara melakukan pematangan calon induk ikan baung jantan dan betina dalam jumlah yang banyak sehingga pembenihan melalui pemijahan buatan akan dapat dilakukan setiap saat.

5. Kendala yang ditemukan oleh Kelompok Budidaya Ikan (Pokdakan) Mina Karya dalam melakukan teknologi budidaya melalui teknologi budidaya intensif ikan baung adalah tingginya harga pakan buatan (pellet) untuk pembesaran yang dilakukan sehingga biaya produksi yang dibutuhkan jug tinggi, namun kendala ini dapat diatasi dengan cara membuat pakan buatan (pellet) sendiri menggunakan bahan-bahan yang ada di lingkungan kelompok tani sehingga kendala biaya yang tinggi dalam penyediaan pakan buatan (pellet) ini akan dapat diatasi.

\section{Saran}

Dari hasil kegiatan program kemitraan masyarakat (PKM) yang telah dilakukan tentang teknologi pembenihan ikan baung melalui pemijahan buatan pada Kelompok Pembenihan Rakyat (KPR) Lele Sejahtera dan teknologi budidaya melalui teknologi budidaya intensif ikan baung pada Kelompok Budidaya Ikan (Pokdakan) Mina Karya Desa Batu Belah, Kecamatan Kampar, Kabupaten Kampar, Riau ini dapat disarankan kepada pihak pemerintah kususnya dinas Perikanan dan Kelautan agar dapat membina kelanjutan kegiatan yang telah dimulai oleh kedua kelompok tani tersebut, baik tentang teknologi pembenihan ikan baung melalui pemijahan buatan maupun tentang teknologi budidaya melalui teknologi budidaya intensif ikan baung. 


\section{Daftar Pustaka}

Sukendi dkk.

1. Alawi, H., M. Ahmad, Rusliadi, and Pardinan. 1992. Some biological aspects of catfish (Macrones nemurus CV) from Kampar River. Berkala Perikanan Terubuk 18(52): 32-47.

2. Djajadiredja, R., S. Hatimah, dan Z. Arifin. 1977. Buku pedoman pengenalan sumber perikanan darat. Bagian I. Jakarta: Direktorat Perikanan Departemen Perikanan.

3. Harker, K. 1992. Pembiakan kap dengan menggunakan ovaprim di India. Warta Akuakulture 2(3).

4. Kottelat, M, J.W. Anthony, N.K. Sri, dan W. Soetikno. 1993. Freshwater fishes of Western Indonesia and Sulawesi (ikan Air Tawar Indonesia Bagian Barat dan Sulawesi). Periplus Editions (HK) Ltd, Proyek EMDI Menteri Negara Kementerian Lingkungan Hidup Republik Indonesia.

5. Nandeesha, M.C., K.G. RAO. R. Jayanna, N.C. Parker, T.J. Varghese, P. Keshavanah, and H.P.C. Shetty. 1990. Induced spawning of Indian mayor carps through single aplication of ovaprim, In Hirano and I. Hanyu, eds The Second Asian Fisheries Society, Manila p. 36-71.

6. Nurman. 1995. Pengaruh kombinasi penyuntikan ovaprim dan $\mathrm{PGF}_{2} \alpha$ terhadap kualitas spermatozoa ikan lele dumbo (Clarias gariepinus Burcheel). Tesis Magister Sains Program Pascasarjana, Institut Pertanian Bogor.

7. Putra, R.M., dan Sukendi. 1998. Pengaruh Kombinasi Penyuntikan Ovaprim dan PGF $2 \alpha$ terhadap volume semen dan kualitas spermatozoa ikan klemak (Leptobarbus hoeveni Blkr). Pekanbaru: Lembaga Penelitian Universitas Riau.

8. Putra, R.M., dan Sukendi. 2000. Peningkatan volume semen dan kualitas spermatozoa ikan baung (Mystus nemurus CV) melalui penyuntikan ovaprim. Pekanbaru: Lembaga Penelitian Universitas Riau.

9. Putra, R.M., Sukendi, dan Pardinan. 2000. Pengaruh lama penyimpanan mani pada konsentrasi methanol berbeda terhadap kualitas spermatozoa ikan baung (Mystus nemurus CV) melalui penyuntikan ovaprim. Pekanbaru: Lembaga Penelitian Universitas Riau.

10. Putra, R.M., Sukendi, dan Yurisman. 2011. Pengaruh kombinasi penyuntikan ovaprim dan prostaglandin $\mathrm{F}_{2} \alpha$ terhadap volume semen dan kulaitas spermatozoa ikan selais (Ompok hypophthalmus). Berkala Perikanan Terubuk 39(2): 67-76.

https://ejournal.unri.ac.id/index.php/JT/article/view/279

11. Saanin, H. 1984. Taksonomi dan kunci identifikasi ikan. Bagian I. Jakarta: Bina Cipta.

12. Samuel, dan S. Adjie. 1994. Aspek reproduksi dan kebiasaan makan ikan baung (Mystus nemurus CV) di daerah aliran Sungai Batang Hari Jambi. Buletin Penelitian Perikanan Darat 12(2): 59-65.

13. Sukendi, B. Purwantara, S. Sikar, dan A. Hardjamulia. 1996. Pengaruh kombinasi penyuntikan ovaprim dan prostaglandin $\mathrm{F}_{2} \alpha$ terhadap daya rangsang ovulasi dan kualitas telur ikan lele dumbo (Clarias gariepinus Burcheel). Berkala Perikanan Terubuk 22(65): 50-60.

14. Sukendi, R.M. Putra, dan Nur'Asiah. 2014. Peningkatan daya rangsang ovulasi dan mutu telur serta volumen semen ikan senggaringan (Mystus nigriceps CV) untuk kebutuhan pemijahan buatan dalam produksi benih. Pekanbaru: Fakultas Perikanan dan Ilmu Kelautan Universitas Riau.

15. Sukendi, R.M. Putra, dan Yurisman, 2006. Teknologi pembenihan dan budidaya ikan kapiek (Puntius schwanefeldi Blkr) dari Perairan Sungai Kampar Riau. Pekanbaru: Universitas Riau.

16. Sukendi, R.M. Putra, dan Yurisman. 2010a. The effects density toward growth and survival rate of motan (thynnicthys thynnoides Blkr). Teknobiologi, Jurnal Ilmiah Sains Terapan 1(1): 29-35.

17. Sukendi, R.M. Putra, dan Yurisman. 2010b. Pengaruh kombinasi penyuntikan ovaprim dan Prostaglandin F2 $\alpha(\mathrm{PGF} 2 \alpha)$ terhadap daya rangsang ovulasi dan kualitas telur ikan motan (Thynnicthys thynnoides Blkr). Berkala Perikanan Terubuk 39(2): 95-103.

https://ejournal.unri.ac.id/index.php/JT/article/view/259 
18. Sukendi, Thamrin, dan R.M. Putra. 2015. Teknologi domestikasi dan pematangan gonad ikan pawas (Osteochilus hasselti CV) dari perairan Sungai Kampar, Riau. Dinamika Lingkungan 2(2): 108-120.

19. Sukendi. 1995. Pengaruh kombinasi penyuntikan ovaprim dan prostaglandin $F_{2} \alpha$ terhadap perubahan histology ovarium ikan dumbo (Clarias gariepinus Burcheel). Pekanbaru: Lembaga Penelitian Universitas Riau.

20. Sukendi. 1996. Pengaruh kombinasi penyuntikan ovaprim dan prostaglandin $F_{2} \alpha$ terhadap daya rangsang ovulasi dan kualitas telur ikan betutu (Oxyeleotris marmorata Blkr). Berkala Perikanan Terubuk 23(68): 78-87.

21. Sukendi. 2001. Biologi reproduksi dan pengendaliannya dalam upaya pembenihan ikan baung (Mystus nemurus CV) dari Perairan Sungai Kampar Riau. Disertasi Program Pascasarjana, Institut Pertanian Bogor.

22. Sukendi. 2007. Baung, biologi, reproduksi, pembenihan dan budidaya. Pekanbaru: Mina Mandiri Press, CV Mina Mandiri Pekanbaru.

23. Sukendi. 2012. Pengaruh kombinasi penyuntikan ovaprim dan prostaglandin $F_{2} \alpha$ terhadap daya rangsang ovulasi dan kualitas telur ikan motan (thynnicthys thynnoides Blkr). Berkala Perikanan Terubuk 40(1): 13-21. https://ejournal.unri.ac.id/index.php/JT/article/view/283 